\title{
CONTRIBUTION OF TRMM RAINFALL DATA TO THE STUDY OF NATURAL SYSTEMS AND RISK ASSESSMENT. CASES OF APPLICATION IN SW ANGOLA
}

\author{
P.A. DINIS ${ }^{(1)}$, V. MANTAS ${ }^{(2)}$, P.S. ANDRADE ${ }^{(3)}$, J. TONECAS $^{(4)}$, E. KAPULA ${ }^{(5)}$, A. PEREIRA $^{(6)}$ \& F.S. \\ CARVALHO ${ }^{(2)}$
}

Abstract:

\begin{abstract}
Researchers studying exogenous processes in developing countries have to deal with the problem of scarcity of rainfall data. With satellite measurements, such as those provided by the Tropical Rainfall Measuring Mission (TRMM), it may be possible to overcome this limitation. In this work we link the TRMM rainfall measurements with two examples of exogenous processes from southwest Angola: slope instability, focused on the events at the Leba road in early 2011, and flow conditions, based on the water level determined in gauging stations from rivers Cavaco and Catumbela. It is demonstrated that major mass flow movements occur when specific TRMM rainfall thresholds are reached. Regarding the flow conditions, the water level in the two gauging stations is conditioned by other factors beside the rainfall in their watersheds, some related to human activities, but short term oscillations are closely linked with the rainfall in the proximity. TRMM data is found to be very useful for the analysis of specific extreme events or the patterns of behavior of natural systems and, consequently, constitute a valuable tool in natural risks assessment.
\end{abstract}

Palavras-chave: Idade do Bronze, contextos e práticas funerárias, monumento sob tumulus, cista "megalítica", oferendas cerâmicas.

Resumo: Contribuição dos dados TRMM para o estudo de sistemas naturais e avaliação de riscos. Casos de aplicação no SW de Angola

Os investigadores que estudam processos exógenos nos países em desenvolvimento lidam com o problema da escassez de dados pluviométricos. Com dados de satélite, como os fornecidos pela Tropical Rainfall Measuring Mission (TRMM), será possível superar essa limitação. Neste trabalho relacionamos os valores de precipitação TRMM com dois exemplos de processos exógenos no sudoeste de Angola: movimentos de massa, focados nos acontecimentos ocorridos na estrada da Leba no início de 2011, e as condições de escoamento, com base no nível de água determinado em estações hidrométricas nos rios Cavaco e Catumbela. Demonstra-se que os maiores movimentos de massa ocorrem quando determinados limiares de precipitação TRMM são alcançados. Em relação às condições de escoamento, o nível de água nas duas estações hidrométricas é fortemente condicionado por outros fatores para além da precipitação ocorrida nas áreas de drenagem, alguns relacionados com actividades do Homem, mas as oscilações de curto período estão intimamente ligadas à intensidade da precipitação que ocorre nas proximidades das referidas estações. Os dados TRMM revelam-se muito úteis para a análise de eventos extremos específicos ou de padrões de comportamento de sistemas naturais superficiais e, consequentemente, constituem uma ferramenta valiosa na avaliação de riscos naturais.

Palavras-chave: Dados de precipitação TRMM, Avaliação de riscos, Deslizamento, Nível da água no canal, Angola

Received: 13 September 2013; Accepted: 6 November, 2013

\section{INTRODUCTION}

The nature and intensity of exogenous processes, such as those associated with the weathering and erosion of rock massifs, slope instability, sediment deposition and flooding in river valleys, are determined by climate variables and the geology (especially the lithology and the structural features) and relief characteristics of the regions where they take place. With regard to the climate variables, rainfall plays a key role. On one hand, it directly influences weathering and erosion processes and affects slope dynamics and the flow regime in river systems. On the other hand, rainfall determines the geotechnical behaviour of soils and rocks, which in turn is reflected on the surface process referred above. Furthermore, the intensity and seasonal distribution of rainfall determine some biogeographic parameters of the regions, like the type and density of vegetation cover, and these parameters influence the magnitude of the processes responsible for changes in the landscape.

To achieve a proper interpretation of natural processes on the Earth's surface it is essential to have accurate weather data. Unfortunately, in many parts of the globe, there is not a sufficiently dense

\footnotetext{
(1) IMAR-CMA Centro do Mar e Ambiente, Departamento de Ciências da Terra da Universidade de Coimbra, Largo Marquês de Pombal. $3000-272$ Coimbra, Portugal,pdinis@dct.uc.pt

(2) IMAR-CMA Centro do Mar e Ambiente

(3) Centro de Geociências, Departamento de Ciências da Terra da Universidade de Coimbra, Largo Marques de Pombal. 3000-272 Coimbra, Portugal

${ }^{(4)}$ Serviço Nacional de Protecção Civil e Bombeiros, Delegação Provincial de Benguela, República de Angola

${ }^{(5)}$ Escola de Formação de Professores do Ensino Médio, Quilengues, República de Angola

${ }^{\left({ }^{6}\right)}$ IMAR-CMA Centro do Mar e Ambiente, Departamento de Ciências da Terra da Universidade de Coimbra, Largo Marquês de Pombal. $3000-272$ Coimbra,
} Portugal 
network of meteorological stations with long time series to understand weather patterns and their spatial variability. The need for data is particularly important when natural processes are potentially hazardous. The issue becomes also urgent when dealing with poorly known regions where the population has been rapidly growing and in a disordered way (e.g. ALCÁNTARA-AYALA 2002), as is the case for many areas of southwestern Angola.

This paper deals with an analysis of rainfall data obtained through the Tropical Rainfall Measuring Mission (TRMM - http://pmm.nasa.gov/ node/158). The pattern of rainfall is expected to play a key role in two cases of natural processes, associated with slope dynamics and fluvial behavior, observed in the southwest of Angola (Fig. 1). The slope dynamic case study refers to the landslide events that took place in early 2011 in the Leba hills (GOMES-LEAL \& TEIXEIRA-PINTO 2012; KAPULA 2012). The assessment of river flow conditions is based on a set of water level measurements obtained in gauging stations installed in rivers Cavaco and Catumbela (TONECAS 2012). In both cases we attempt to establish relationships between the exogenous processes and the coeval rainfall intensities in the areas of influence.

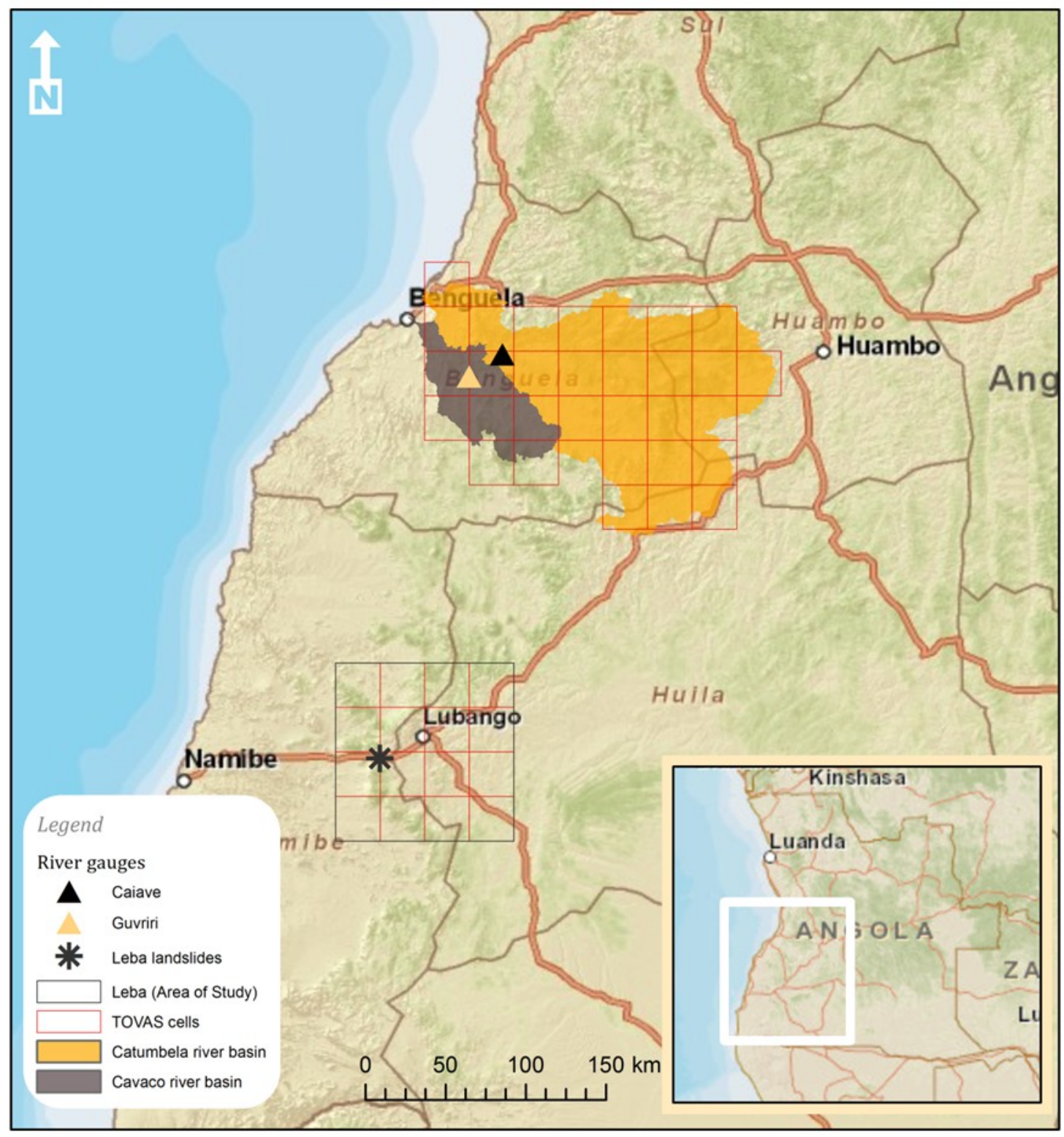

Fig. 1. Map showing key locations of the presented case studies from southwest Angola. It is represented the location of Leba road affected by mass flow events, watersheds of rivers Catumbela and Cavaco, gauging stations in these rivers and TRMM cells used for the acquisition of rainfall data.

Fig.1. Mapa mostrando locais-chave dos estudos de caso apresentados para o sudoeste de Angola. É representada a localização da estrada da Leba afetada por processos de instabilidade de taludes, as bacias hidrográficas dos rios Catumbela e Cavaco, as estações hidrométricas nestes rios e as células TRMM utilizados para a aquisição de dados de precipitação. 


\section{TRMM RAINFALL DATA}

Given the scarcity of in situ rainfall measurements, remote sensing data could provide valuable information for the study of exogenous processes. TRMM is a Japanese-American joint venture launched in 1997 that provides researchers with regular rainfall estimates from a suite of several instruments (LIU et al. 2007). These data are available at the Goddard Space Flight Center from the North America's Space Agency (NASA).

The TRMM datasets were reinforced with the introduction of multi-mission products (3B42 and 3B43) which are available for a significant portion of the globe $\left(50^{\circ} \mathrm{N}-\mathrm{S}\right)$ (HUFFMAN et al. 2007). The Multi-satellite Precipitation Analysis (TMPA) products are available at the TRMM Online Visualization and Analysis System (TOVAS) (LIU et al. 2012), which is one of the instances available at NASA's Giovanni data access portal (BERRICK et al. 2009). The datasets can be obtained from archives for different intervals and as near real time versions. For the two study areas, daily data from the archived products $3 \mathrm{~B} 42$ were acquired.

\subsection{Cases of application in southwestern Angola}

Two examples of natural processes strongly influenced by rainfall from southwestern Angola were selected for this work. These are:

1) Hazardous slope dynamics in the hills of Leba, near the border between Huíla highlands and the lower elevation Namibe province. Particular attention was given to the events that occurred at the beginning of the year 2011 leading to the closure of an important road (National Highway 280 - EN 280) that links the coastal region with the inland. LealGomes and Teixeira-Pinto (2012) and Kapula (2012) had already described the landslides associated with those mass flow processes.

2) Hydrologic flow conditions in Cavaco and Catumbela rivers, whose outlets are located near Benguela, based on a time series of water level measurements from two gauging stations run by the Angolan Civil Protection and Fire Services. The periodic floods of these rivers have caused significant damages to the local population, including human casualties, houses destruction and crop losses. The water level data used in this work was obtained between January 2008 and March 2010 and previously presented by Tonecas (2012).

The Cavaco and Catumbela drainage basins were delineated from a Digital Elevation Model (DEM), using standard spatial analysis techniques. The DEM applied in this analysis was a subset of the research grade imagery provided by the Shuttle
Topography Radar Mission (SRTM) 90-meter product acquired from the Earth Explorer website of the United States Geological Survey (USGS). A careful definition of the limits of the Cavaco and Catumbela drainage basins was conducted and fine scale corrections introduced where possible, especially in the regions closest to the shore where multiple watersheds were automatically erroneously generated due to the reduced slope and because of errors known to exist in the SRTM data.

Rainfall data were retrieved from NASA's TOVAS data access portal. Different products are available at this instance of Giovanni, including the TMPA. The TMPA was selected since it provides rainfall estimates using a combination of different sensors, thus increasing accuracy, coverage and resolution (HUFFMAN et al. 2007). These products are generated in a four-step process which encompasses the calibration and merge of microwave precipitation estimates, infrared (IR) precipitation retrievals, merging of microwave and IR estimates and, finally, incorporation of rain gauge data for non-real time datasets.

The rainfall estimates thus created and made available at Giovanni, are distributed with a spatial resolution of $0.25^{\circ}$, while covering most of the globe. The data, from the period of interest, were acquired for each cell containing sections of the Cavaco and Catumbela drainage basins and later combined for analysis. The cells from which data were retrieved are displayed in figure 1. Prior to basin-wide analysis, the 3-hourly rainfall estimates were summed to generate a daily product, compatible with the river gauge information. The daily rainfall estimates, in $\mathrm{mm} /$ day, were combined for each drainage basin. The values for each cell were summed (without taking into account the area of watershed covered by each TOVAS cell) and a standard statistical analysis was applied to the output results.

For the second study area, at Leba, the same procedure was adopted, including the retrieval of 3B42 Accumulated Rainfall, but instead of a segmented acquisition, a single block was defined for a $1 \times 10$ cell (Fig. 1). The available data was extracted and analyzed in the same way as for the Cavaco and Catumbela watersheds, with the standard statistical parameters being calculated for the area of interest.

\section{GEOLOGICAL AND GEOMORPHOLOGICAL SETTING}

A striking aspect of the southwestern area of Angola is the presence of flattened surfaces separated by more or less steep steps, which have been used to delimit the major geomorphological units (Jessen, in FEIO 1946; FEIO 1981; DINIZ 2006). The Surface of Humpata (level V of Jessen) is the highest surface, reaching 2000 to 2300 meters 
in elevation. It is surrounded, to the east, by the Main Plateau (level IV of Jessen), and to the west by a much lower surface, which is usually more than 1000 meters below (FEIO 1981). An extensive region of Angola that is more than 1500 meters high, which integrates the Surface of Humpata and the Main Plateau, has been called the Central Plateau. Marques $(1966,1977)$ assigns the term Marginal Mountains Range (Cordilheira Marginal de Montanhas) to an area that is broadly oriented parallel to the Atlantic coast and marked by the presence of the highest flattened surfaces of Angola. The boundary between the drainage basins of the rivers that flow directly to the west (eg., the rivers Catumbela and Cavaco) and others facing south and east, integrating the drainage basins of the Kunene and Cubango rivers, is located at this mountain range.

Along the Main Plateau outcrop mainly Paleoproterozoic igneous rocks, associated with the Eburnean igneous cycle, which intrude an older complex unit with metamorphic and igneous rocks that may already belong to the Archean (PEREIRA et al. 2011). The Eburnean magmatic units are covered by a stratified succession formed by the Chela Group and the Leba Formation that is well represented in the Surface of Humpata (CARVALHO 1981). At the zone of contact between the Eburnean magmatic rocks and the overlying succession the former are usually deeply weathered.

The Chela Group and the Leba Formation were described in detail by Correia (1976). According to this author, the Chela Group consists of four formations, namely: Tundavala Fm. (mainly detrital, comprising conglomerates, sandstones and quartzites); Humpata Fm. (volcano-sedimentary rocks, associated with acid volcanism, sometimes with interlayers of intrusive rocks); the Bruco Fm. (mainly detrital, distinguished from the previous units by the scarcity of volcanic rocks and coarser sediment grain size); and the Cangalongue Fm. (consisting essentially of fine-grained sedimentary rocks and carbonates). The Leba Fm., which stands on the Chela Group, consists mainly of silicified and dolomitic limestones (CORREIA 1976). One of the most relevant aspects of this unit is the presence of well-preserved stromatolitic structures. Both units are affected by several joint systems, part of them sub-vertical, and faults. The units display open folds and flexures, although, in general, stratification dip angles are low.

In the westernmost fringe of southwestern Angola outcrop Mesocenozoic sedimentary rocks belonging to the Benguela sub-basin, which has been considered the southern part of the Kwanza Basin (PINTO \& CARVALHO 2010), and the Namibe Basin. In general, the Mesocenozoic units overlay metamorphic rocks of the Paleoproterozoic or Archean complex (CARVALHO 1983). A clear topographic step that, in places, reaches 100 meters is observed at the transition between the NamibeBenguela basins and the pre-Mesozoic basement (FEIO 1981; GUIRAUD et al. 2010).

Broadly speaking, the climate of Angola is characterized by an interchange of a wet season and a dry season. The wet season, during which most rainfall takes place, is also marked by higher temperatures. This season usually runs from September to April, depending, however, on the geographical area. The dry season is colder and usually runs from May to September. According to Koppen's classification, in the area of Benguela, the climate type is BSh (hot semi-arid), evolving towards the interior to Cwa (humid sub-tropical) and Cwb (temperate highland tropical with dry winters), and towards the south to BWh (hot desert) (PEEL et al. 2007). At Leba the climate is classified as Cwb. According to Thornthwaite classification, the climate is arid in the western margin, with the highest dryness in southern locations, changing to mesothermal and humid or sub-humid in innermost positions of the center-west of Angola (DINIZ 2006). From the climate classification of southwestern Angola, it is expected that rainfall is reduced along the coast, increasing significantly inland.

Some general features of the areas related to the case studies presented in this work are summarized in Table 1. The Cavaco river catchment is located entirely in the sub-plateau area, draining rocks of the Benguela Basin and the old metamorphic-magmatic complex; the Catumbela catchment extends into the Central Plateau where Eburnean magmatic rocks outcrop throughout a large area. The region of Leba is located at the

Table 1. General features of the study cases

Tabela 1. Características gerais dos casos de estudo.

\begin{tabular}{lccc}
\hline \multicolumn{1}{c}{ Case study } & Leba & $\begin{array}{c}\text { Cavaco } \\
\text { (drainage basin) }\end{array}$ & $\begin{array}{c}\text { Catumbela } \\
\text { (drainage basin) }\end{array}$ \\
\hline Latitude & $-15,06$ to $-15,08$ & $-12,56$ to $-13,38$ & -12.37 to $-13,79$ \\
& 13,22 to 13,24 & 13,41 to 14,26 & 13,47 to 15,44 \\
\hline Longitude & - & 3512 & 11641 \\
\hline Area $\left(\mathrm{Km}^{2}\right)$ & $1300-1900$ & $0-2570$ & $0-1592$ \\
\hline Elevation (m) & Cwb & BSh, Cwa and Cwb & BSh, Cwa and Cwb \\
\hline Climate (Koppen) & & \\
\hline
\end{tabular}


outstanding transition zone between the Central Plateau and a lower elevation region being characterized by the presence of very high and steep slopes. In this area occur mainly Eburnean magmatic rocks covered by the Chela Group and the Leba Fm.

\section{SLOPE INSTABILITY ON LEBA HILLS}

\subsection{Instability processes}

Both natural and cut slopes along Leba hills are frequently very steep and the weathering degree of
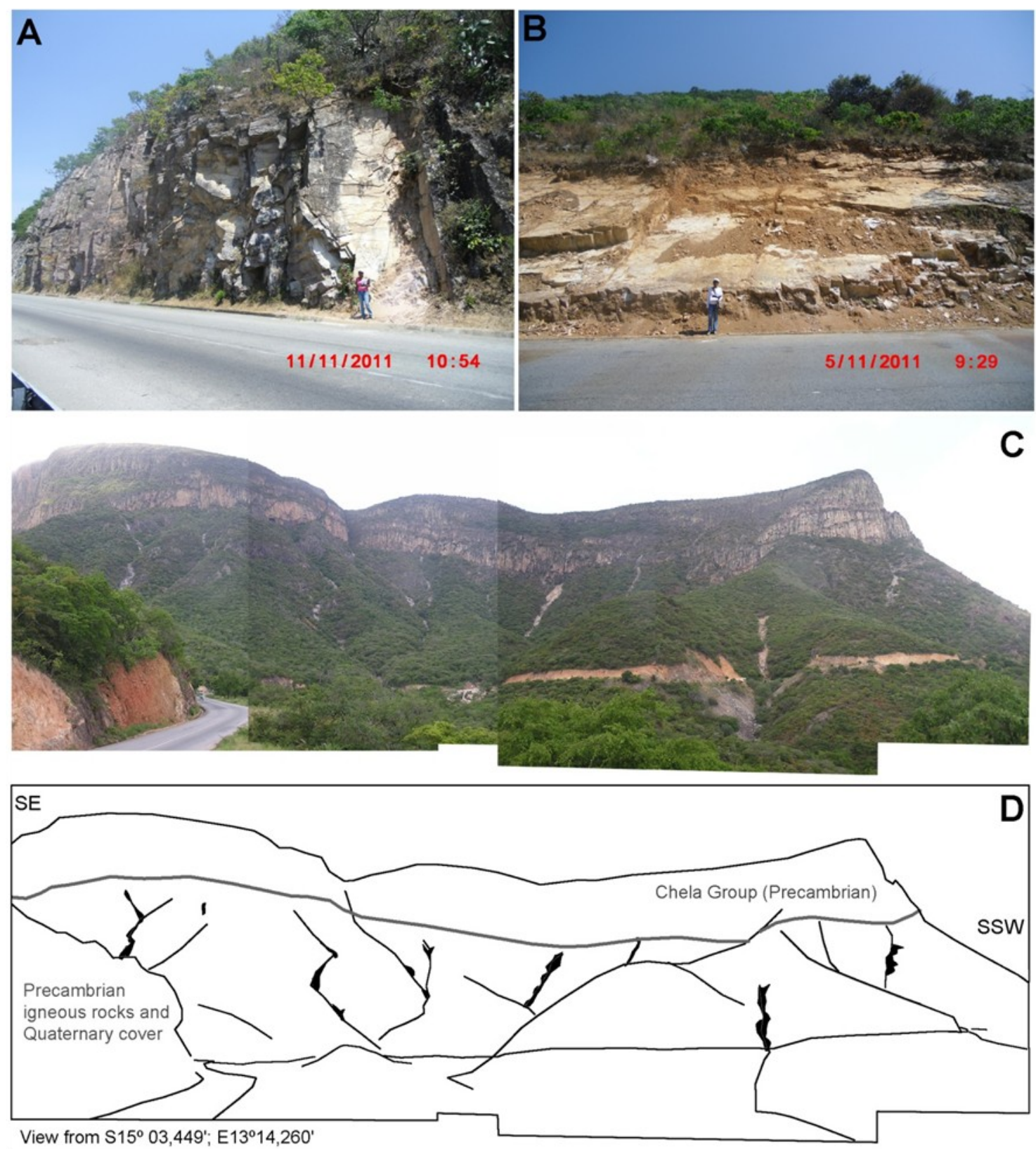

Fig.2. Examples of mass movement in the Leba road and surrounding area. Rock falls and wedge failure (A); planar failure (B) affecting stratified units of the Chela Group. Photomosaic (C) and image interpretation (D) of an area affected by mass flow. Black patches represent mass flow sites.

Fig.2. Exemplos de movimentos de massa na estrada Leba e área circundante. Queda de blocos e deslizamentos em cunha (A) e deslizamento planar (B ) afetando unidades estratificadas do Grupo da Chela. Fotomosaico (C) e imagem de interpretação (D) de uma área afetada por fluxos de massa. Manchas pretas representam locais com fluxos de massa.

the outcropping units tends to be high. Hence, driving forces can overcome resistance forces, such as cohesion and friction, and originate slope movements. These features of the topography and structure, coupled with the periodically landslides along the slopes of Leba hills (Fig. 2) Slope movements occur periodically along road EN 208 even when the weather conditions are not marked by severe rainfall. However, during these events usually minor volumes are displaced and the consequences for the road circulation tend to be limited. 
Rock falls, translational rockslides and toppling failures occurred at the beginning of 2011 in several slopes of road EN 280 where rocks of the Chela Group outcrop (Fig. 2). Rock falls and translational rockslides, consisting of planar and wedge failures, are frequent in cut slopes affected by discontinuities of variable orientation and spacing. Rock falls correspond to blocks detached from slopes, and are a common and very rapid type of slope instability along the study area. The rough topography and high slopes, the close joint spacing and its orientation have a clear influence on triggering rock fall movements. Planar rockslides are associated with three major joint sets. Wedge failures occur at main discontinuities intersections. Translational rockslides are relatively less common than rock falls along the studied area. Toppling failures are characteristic of very steep slopes with tens of meters high that present sub-vertical and highly penetrative discontinuities. Toppling failures did not represent a major threat to the road traffic, since they occurred in sites located several tens of meters from the EN 280.

Mass flow phenomena, which correspond to debris and soil flows, occurred in lower elevation sites along the descent of Leba, always below the steep slopes found in the stratified formations of the Chela Group and in locations with a higher density of vegetation cover that developed on the weathering mantles of the granitic massifs or covering colluvial deposits (Fig. 2). The debris flow deposits integrate a diversified set of lithological types derived both from the Eburnean magmatic rocks and the overlying Chela Group. These slope movements have made huge damages along the road EN 280, leading to its disruption for several days in April 2011.

\subsection{Relationship between the phenomena of instability and rainfall}

The slope instability events in the Leba hills during the beginning of 2011 are expected to be intimately linked with the rainfall intensity. During this period the number of days without rainfall was reduced (14 days, $12 \%$ of the record between January and April 30), although most days had daily rainfall below $5 \mathrm{~mm}(55.8 \%)$. But the slope instability period is marked by significant frequency of days with rainfall exceeding $20 \mathrm{~mm}$ $(13.3 \%)$ and $30 \mathrm{~mm}(4.2 \%)$, and the occurrence of 2 days with rainfall close to, or even higher than, $50 \mathrm{~mm}$ (Fig. 3). When considering the entire record (5479 days), the class with rainfall below 5 $\mathrm{mm}$ is clearly dominant $(85.2 \%)$ and the frequencies of days with rainfall above $20 \mathrm{~mm}$ and $30 \mathrm{~mm}$ are just $1.9 \%$ and $0.5 \%$, respectively.

The atmospheric precipitation in the early

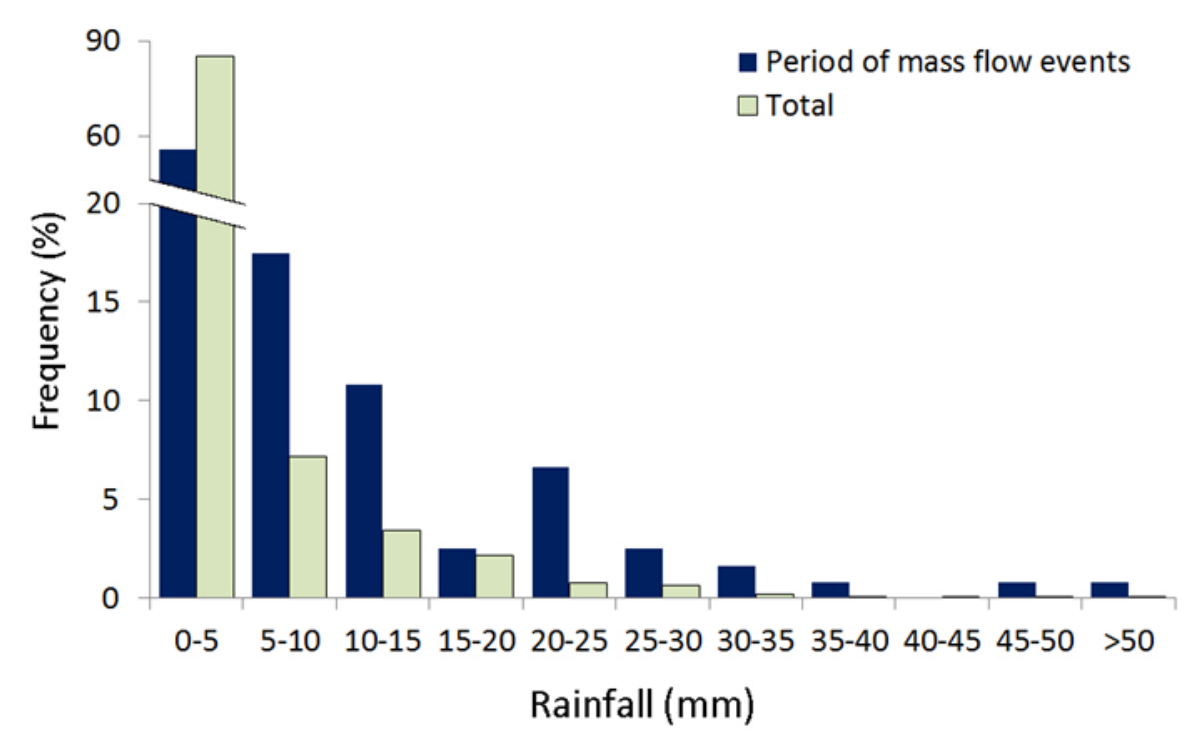

Fig.3. Comparison of TRMM rainfall data in the first trimester of 2011 with the entire record for the selected cell.

Fig.3. Comparação entre os dados de precipitação TRMM no primeiro trimestre de 2011 e a totalidade do registro para a célula selecionada na região da Leba.

2011 can be grouped into four stages (Fig. 4):

- During the first half of January the rainfall was high, with distinctive peaks in January 4 (27 $\mathrm{mm}), 6(38 \mathrm{~mm}), 10(28 \mathrm{~mm}), 11(47 \mathrm{~mm}$, the maximum for this stage) and $13(24 \mathrm{~mm})$.

- After that, for about two weeks, the rainfall was always substantially lower (less than $0.1 \mathrm{~mm}$ ) and several days occurred without any rain. The longest period without rain elapsed between 23 and 26 January, inclusive.

- In the following weeks, between early February and mid-April, there was a succession of days with high rainfall that ended up on April 12. 
The maximum rainfall in this period occurred on April 2 (56 mm). Beside April 2, several days had rainfall exceeding $20 \mathrm{~mm}$.

- The rainfall was substantially lower in the second half of April, never exceeding $10 \mathrm{~mm}$.

The weeks between the beginning of February and the end of the first half of April deserve particular attention. During this period occurred ten days with rainfall exceeding $20 \mathrm{~mm}$, most of them in the first week of March and the first fortnight of April, five in the first week of April; very few days had no rain, all of them in mid-March.
Slope movements happened since the beginning of 2011 , but only led to circulation difficulties along the Leba road during the month of March when slide and rock fall events caused safety problems (Fig. 4). The traffic circulation was significantly disrupted in early April when the road was fully blocked at several points due to voluminous mass flows. The phenomena of slope instability continued on the Leba hills during the subsequent weeks of April, but did not affected the EN 280 and had no implications on vehicles circulation. It thus seems evident that the most significant landslides, given the mobilized volumes and effects on traffic circulation, coincide with

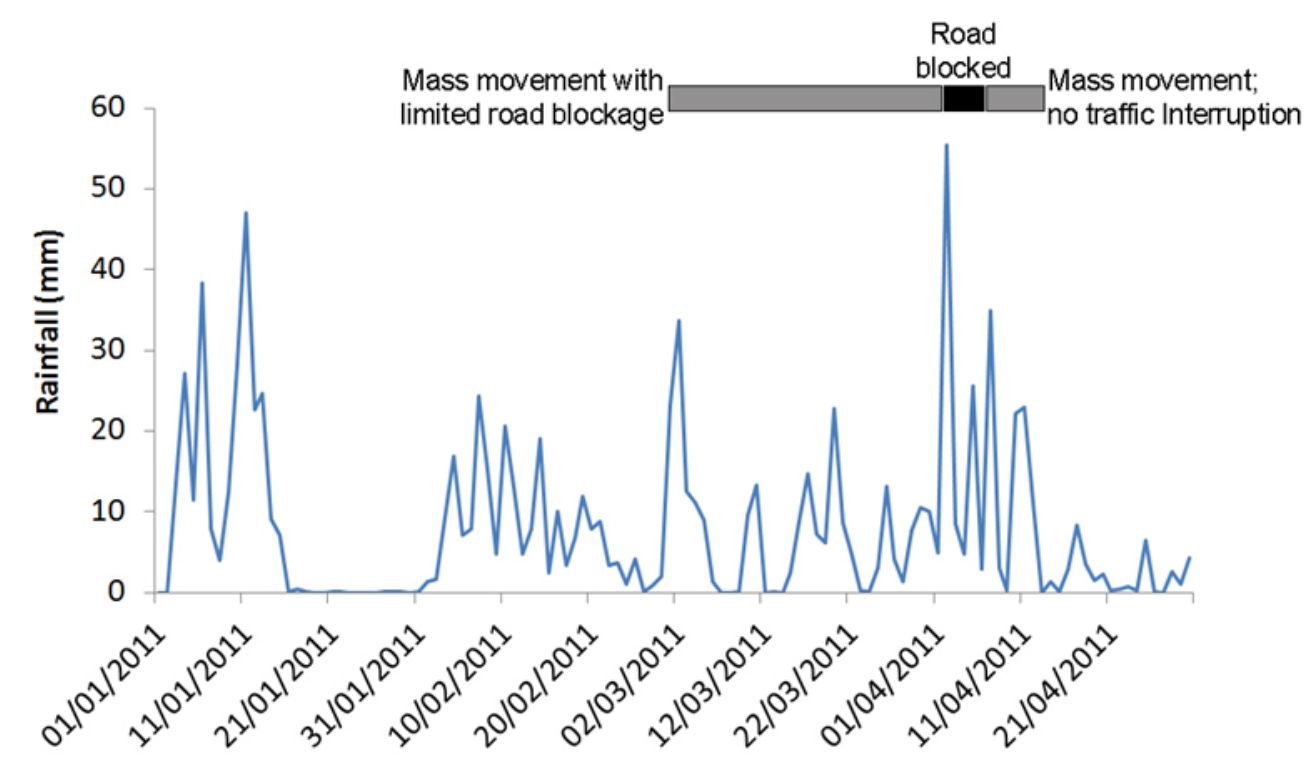

Fig. 4. Daily rainfall during the period of landslide events in the Leba road during the early months 2011.

Fig. 4. Valores diários de precipitação durante os eventos de instabilidade de taludes na estrada Leba dos primeiros meses de 2011.

periods of higher rainfall. They were, however, favored by the intense precipitation that took place during January and increased the water content leading to the saturation of soils and rocks (Fig. 4). Besides the occurrences of early 2011 presented here, previous slope movements took place during periods when daily TRMM rainfall data was found to be close to $40 \mathrm{~mm}$.

Depending on the morphological and geological characteristics of the terrain, there is a rainfall threshold above which the slope movement processes tend to be more severe. For the cases of the landslides on the Leba hills the most notable movements took place when the daily rainfall exceeded $30-40 \mathrm{~mm}$. It seems that the very high rainfall intensity during January 2011 must have also contributed to the magnitude of the March and April events.

\section{WATER FLOW IN RIVERS CAVACO AND CATUMBELA}

\subsection{Drainage conditions}

The seasonal rainfall pattern is responsible for pronounced oscillations in the water level of the rivers of southwestern Angola. In most of them the channels are dry during most time and, as the climate in the western regions is much drier than in the inland, it is frequent to observe noticeable water level rises in the littoral regions, more densely populated, when no precipitation has fallen in these locations, but just in upstream areas.

The Cavaco river has a strong torrential character. When it rains, the water level in the channel network rises suddenly along with the flow 
velocity and the transport capacity. On the other hand, during the floods, the Cavaco river carries a high sediment load that promotes channel siltingup and, consequently, hinders drainage. Given this set of features, the Cavaco river is generally considered hazardous. Furthermore, on the banks of Cavaco occur dense residential areas that sometimes even spread into the channel itself, introducing a high level of vulnerability to flooding
(Figure 5). For these reasons, the flood risk of the Cavaco river is high and it is usually considered particularly problematic by the flood prevention and control authorities in the Benguela province.

The Catumbela river has a more steady behavior. It is perennial, but still with significant flow fluctuations between wet and dry seasons. The alluvial plain of Catumbela and the downstream areas of the valley are regularly

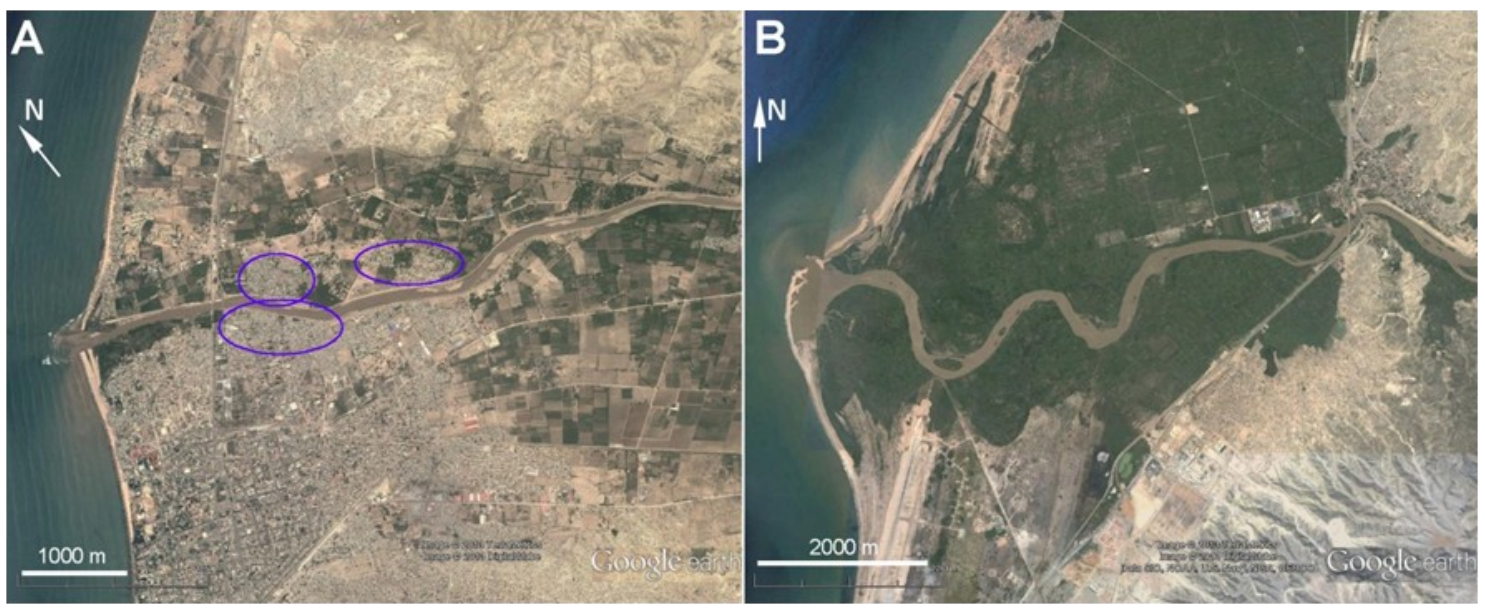

Fig.5. Satellite images (Google Earth TM) of the downstream sectors of the rivers Cavaco (A) and Catumbela (B). Residential areas attached to the channel of Cavaco river are highlighted.

Fig. 5. Imagens de satélite (Google Earth TM) dos setores jusante dos rios Cavaco (A) e Catumbela (B). São realçadas as áreas residenciais encostadas ao canal do rio Cavaco.

flooded due to channel overflow and the rise of the water table. Since the floodplain has primarily agricultural land use (Figure 5), the inundation process are not considered has dangerous to local residents as in the Cavaco river.

Regardless of other morphometric features of the drainage basins of these two rivers, we admit that the highly torrential character of the Cavaco river is partially related to the relationship between the spatial distribution of rainfall and the relief of its catchment. Unlike Catumbela drainage basin, where rainfall is high in its intermediate and inner positions, the utmost rainfall intensities in Cavaco basin are observed at its headwater region. Thus, in this river, rainfall is higher in the sectors of higher gradients, where the infiltration will be lower and the runoff volumes and velocities tend to be particularly elevated.

\subsection{Water level in rivers Cavaco and Catumbela}

Hydrometric data were obtained from gauging stations installed in the Catumbela (Caiave, $72 \mathrm{~km}$ of the coastline) and Cavaco (Guvriri, $58 \mathrm{~km}$ of the coastline). The gauging stations were installed in these places during the colonial times, but they become fruitless during the civil war and it was not possible to obtain measurements from the former operation period.
Both stations are programmed to provide the height of the water column, in meters, with intervals of three hours (00:00, 03:00, 06:00, 09:00, 12:00, 15:00, 18: 00 and 21:00). They are equipped with a sensor for reading the level reached by the waters, a buoy and a ruler. With this system, the buoy runs up and down according to the height of the water in the channel providing automatically information on the flowing level in the rivers that is transmitted to a control station.

The gauging stations in the rivers Catumbela and Cavaco started to provide water heights data at the beginning of January 2008 and 2009, respectively. The logged measurements in both stations have some interruptions due to operational problems (Figs. 6 and 7), particularly at the station in the Cavaco river, where the number of reliable measurements is quite limited. One notable feature of the record is the presence of intervals with stable water that last for a few days. In most cases these intervals are probably "artifacts" attributed to trapping of the measuring buoy by river channel sediments.

In the Cavaco river, a significant part of the results suggest almost no surface flow and sudden upsurges to near $7 \mathrm{~m}$ high. The water level in the Catumbela river station is usually below $1 \mathrm{~m}$ during the dry season, rising up to values in the order of 4 meters during the rainy season, albeit with pronounced swings. In general, there are 


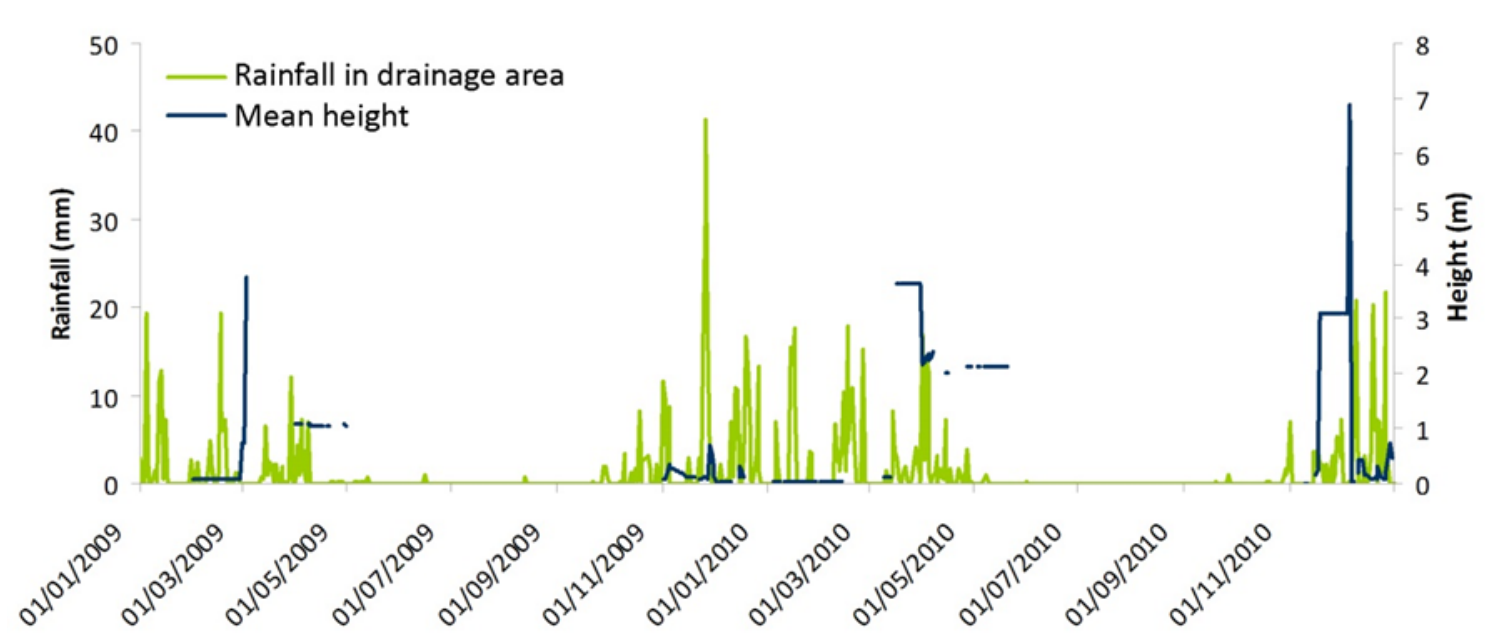

Fig. 6. Evolution of the TRMM daily rainfall in Cavaco river drainage basin and water level measurements obtained for the Guviri gauging station.

Fig. 6. Evolução da precipitação diária TRMM na bacia de drenagem do rio Cavaco e medições de nível da água obtidas para a estação hidrométrica do Guviri .

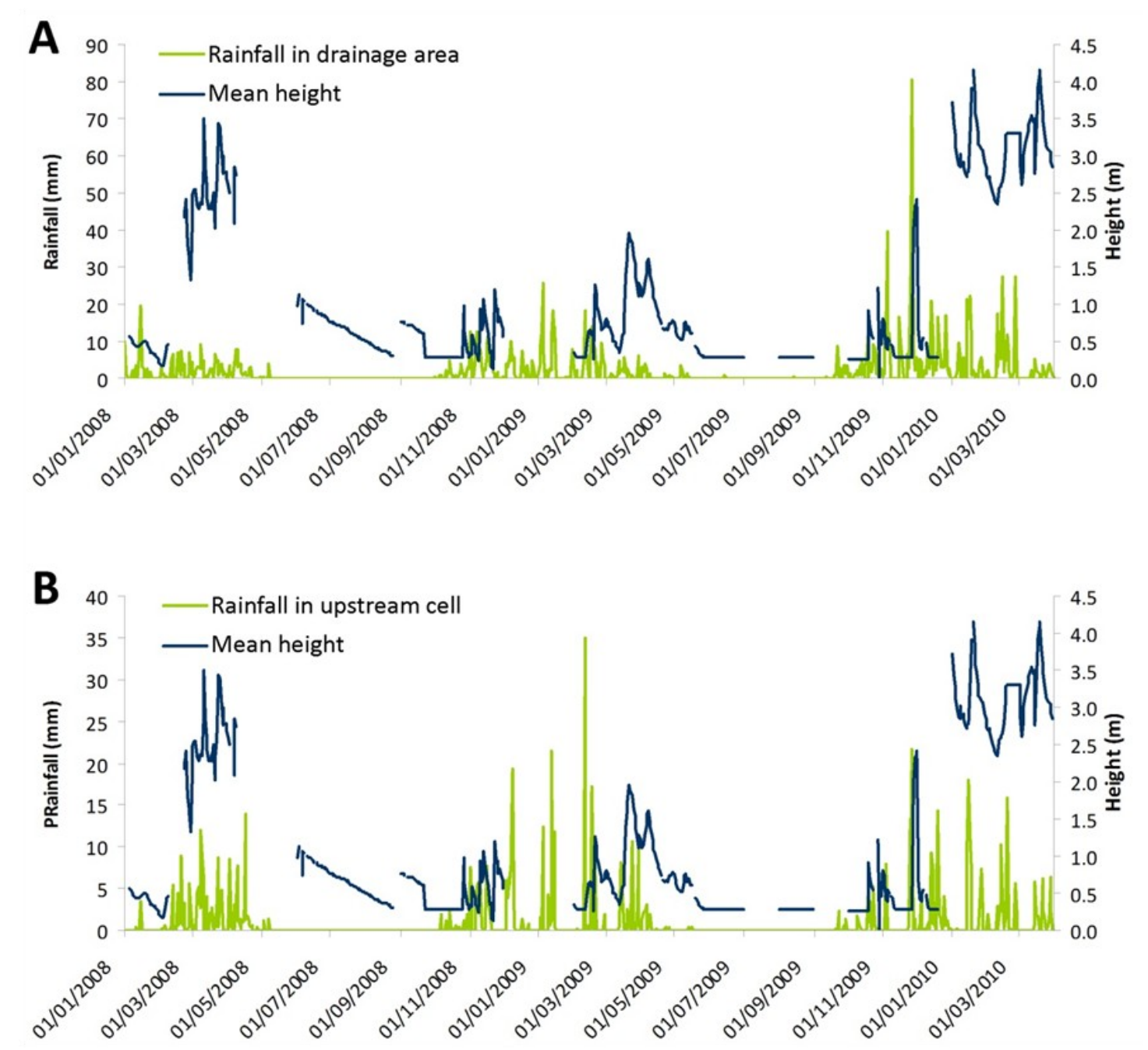

Fig. 7. Evolution of the TRMM daily rainfall and water level measurements obtained for the Caiave gauging station (Catumbela river). (A) Rainfall data from the entire drainage basin (mean cell rainfall within watershed). (B) Rainfall in the cell immediately upstream of the Caiave gauging station.

Fig. 7. Evolução da precipitação diária TRMM e medições de nível da água obtidas para a estação hidrométrica do Caiave (rio Catumbela ). (A) Dados de precipitação na bacia de drenagem (precipitação média para as células no seio da bacia hidrográfica). (B) Precipitação na célula imediatamente a montante da estação hidrométrica do Caiave. 
sudden increases in the water level, often exceeding 1 meter in a day, and a more gradual decrease which may extend for periods of 40 to 80 days.

\subsection{Relationship between rainfall and the water level}

Given the weaknesses of the logged measurements in the Cavaco river station, it is difficult to establish relationships between water level and rainfall in the drainage basin (Fig. 6). With regard to the Catumbela river, as expected, the height of the water column, despite pronounced fluctuations, tends to be higher during the rainy season than during the dry season (Fig. 7). In the weeks following the end or significant decrease of rainfall, a regular and progressive lowering of the water level occurs. If the river flow was not conditioned by human intervention, this progressive lowering could relate to the fact that part of the rain water ended up feeding aquifers, being later released gradually after the decrease of the precipitation and as the river level lowers.

The greater heights of the water column are not always synchronous with a succession of rainy days within the catchment. For example, in the first half of 2008 and the second quarter of 2009, a few days with high water level (near $3.5 \mathrm{~m}$ and $2 \mathrm{~m}$, respectively) occurred when the rainfall in the drainage basin of Catumbela was very low (Fig. 7A). When referring to rainfall data in the cell immediately upstream of the measurement point, it is possible to find a better match between the succession of days of heavy rainfall and the increases in the water level at the hydrometric station (Fig. 7B). It is even possible to find noticeable peaks of water level coinciding with daily rainfall maximums or taking place in the following days. On the other hand, the low rainfall intervals tend to coincide with decreases in water level. Hence, it appears that the short period fluctuations in water level reflect variations of rainfall in areas closer to the Catumbela river gauging station.

The results of the daily mean water level do not correlate with coeval rainfall in the drainage basin (Fig. 8). The lack of correlation is partially justifiable by a variable gap between the moments of rainfall in some point of the watershed and the time when this rain water reached the station through the channel flow. Also, no correlation exists between the water level on a given day and the sum of rainfall in the days that precede the various level measurements. Under these conditions, it seems clear that other factors beyond rainfall intensity have a decisive role in setting the water level. These factors may be natural (e.g. the way rainfall is distributed throughout the watersheds, spatially variable infiltration and runoff, etc) or associated to human action. The systematic extraction of water for urban consumption and irrigation of agricultural fields by the local populations in the area of both stations should be able to introduce some shifts in the water level. Part of the divergences between rainfall and observed water levels may also be attributed to retention and discharge of water in reservoirs and to drainage difficulties due to occasional outflow obstructions.
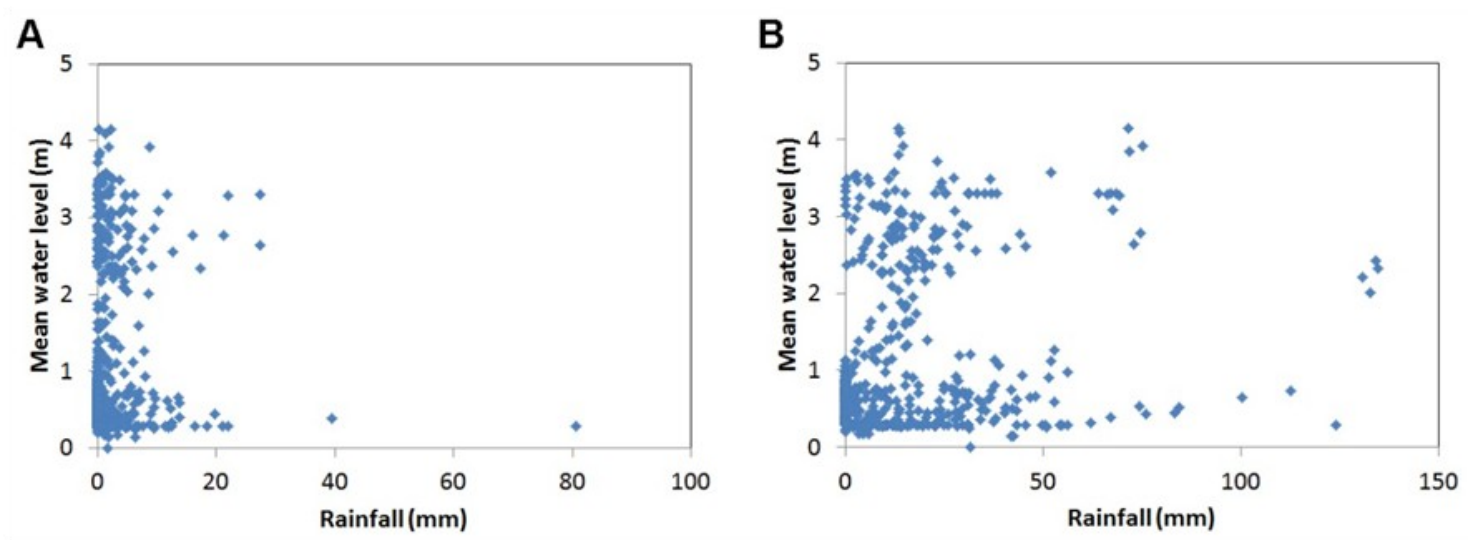

Fig. 8. Relation between daily mean water level in Caiave gauging station (Catumbela river) and TRMM rainfall data in Catumbela drainage basin. Rainfall values during each day (A) and accumulated in 7 days preceding water level measurement (B).

Fig. 8. Relação entre o nível da água médio diário na estação hidrométrica do Caiave e os valores de precipitação TRMM na bacia de drenagem do rio Catumbela. São apresentados valores de precipitação durante cada dia (A) e acumulados nos 7 dias que antecederam a medição do nível da água (B).

\section{CONCLUSIONS}

The TRMM rainfall data were found to be reliable and consistent with the surface processes presented in this work. The analysis of two cases study, one associated with slope movements during a specific and relatively short period and the other with the fluctuations of the river water level throughout a time series of over two years, yielded the following conclusions: 
- The processes of instability on the slopes of Leba in early 2011 are associated with extreme weather conditions marked by high rainfall intensity, especially when it exceeded $30-40 \mathrm{~mm} /$ day. The duration of rainfall and the quantity of water accumulated in the land also influences major landslide processes, in particular mass flows, which are very destructive and could cause the obstruction of the road EN 280.

- Although the water levels in rivers Cavaco and Catumbela tended to be higher during the rainy seasons, there is no correlation between these two variables and irregular lags are observed between them. The relative independence of the two variables indicates that other factors have the ability to condition the general pattern of the rivers water heights. Superimposed on this general pattern, in the Catumbela river occur short term fluctuations in the water level reflecting variations in the intensity of rain at relatively near areas.

The processes considered in this work are closely linked to the risks of flooding and landslide. Risk assessment of surface processes in regions such as Angola can benefit greatly from TRMM rainfall measurements. These data may be very useful for the analysis of specific surface events, more or less extreme, or the patterns of behavior of natural systems in areas where the availability of meteorological data is limited.

\section{ACKNOWLEDGMENTS}

Three reviewers are thanked for their thoughtful comments and suggestions that helped to improve the present work.

\section{REFERENCES}

AlCÁNTARA-AYALA, I. 2002. Geomorphology, natural hazards, vulnerability and prevention of natural disasters in developing countries. Geomorphology, 47: $107-124$.

Berrick, S.W.; LePtoukh, G.; FArley, J.D. \& RUi, H. 2009. Giovanni: A Web service workflow-based data visualization and analysis system. IEEE Transactions on Geosciences and Remote Sensing, 47: 106-113.

CARvalho, H. 1983. Notice explicative preliminaire sur la geologie de l'Angola. Garcia Orta, 6: 15-30.

CORREIA, H. 1976. O grupo Chela e a formação Leba como novas unidades litoestratigráficas resultantes da redefinição da formação da Chela na região do planalto da Humpata : sudoeste de Angola. Boletim da Sociedade Geológica de Portugal, 20: 65-130.

Diniz, A. C. 2006. Características Mesológicas de Angola. IPAD, Lisboa, Portugal.

FEIO, M. 1946. O relevo de Angola, Segundo Jessen. Boletim de Geologia de Portugal, 5: 295-306.
FEIO, M. 1981. O relevo do Sudoeste de Angola. Estudo de Geomorfologia. Memórias da Junta de Investigações Científicas do Ultramar.

Guiraud, M.; Buta-Neto, A. \& Quesne, D. 2010 Segmentation and differential post-rift uplift at the Angola margin as recorded by the transform-rifted Benguela and oblique-to-orthogonal-rifted Kwanza basins. Marine and Petroleum Geology, 27: 10401068 .

Huffman, G.; Adler, R.; Bolvin, D.; Gu, G.; Nelkin, E.; Bowman, K.; Hong, Y.; Stocker, E. \& WolfF, D. 2007. The TRMM Multisatellite Precipitation Analysis (TMPA): Quasi-Global, Multiyear, combined-sensor precipitation estimates at fine scales. Journal of Hydrometeorology, 8: 38 -55.

KAPULA, E. 2012. Instabilidade de taludes na descida da Leba (Humpata, Angola). Unpublished MsC Thesis, Universidade de Coimbra.

LeAl-Gomes, M.J.A. \& TeIXeIRA-Pinto, A. 2012. Notas sobre a Estabilidade de Taludes e Ravinamentos na Estrada da Leba, na Serra da Chela (nota técnica). Geotecnia, 124: 81-89.

LiU, Z., Ostrenga, D., Teng, W. \& Kempler, S. 2012 Tropical Rainfall Measuring Mission (TRMM) Precipitation Data and Services for Research and Applications. Bulletin of the American Meteorological Society, doi: http:// dx.doi.org/10.1175/BAMS-D-11-00152.1

LiU, Z.; Rui, H., Teng, W. L., Chiu, L. S., Leptoukh, G. G. \& ViCENTE, G. A. 2007. Online visualization and analysis: A new avenue to use satellite data for weather, climate and interdisciplinary research and applications. Measuring Precipitation from Space EURAINSAT and the future. Advances in Global Change Research, 28: 549-558.

MARques, M.M. 1966. Les grandes unités géomorphologiques d'Angola. Boletim dos Serviços de Geologia e Minas de Angola, 13: 13-16.

MARquES, M.M. 1977. Esboço das grandes unidades geomorfológicas de Angola (2 $2^{\mathrm{a}}$ aproximação). Garcia de Orta, 2: 41-44.

Peel, M.C.; Finlayson, B.L. \& McMahon, T.A. 2007. Updated world map of the Koppen-Geiger climate classification. Hydrology and Earth System Sciences, 11: 1633-1644.

Pereira, E.; TAssinari, C.C.G.; Rodrigues, J.F. \& VANDúNEM, M.V. 2011. New data on the deposition age of the volcano-sedimentary Chela Group and its Eburnean basement: implications to post-Eburnean crustal evolution of the SW of Angola. Comunicações Geológicas, 98: 29-40.

PInHo, A.C. \& CARvalho, F.F. 2010. Prospecção, pesquisa e produção de petróleo em Angola. O papel desempenhado pelas companhias petrolíferas. In J.M. Cotelo Neiva, A. Ribeiro, L. Mendes Victor, F. Noronha e M. Magalhães Ramalho (Eds.) Ciências Geológicas - Ensino e Investigação e sua história. Lisboa: Associação Portuguesa de Geólogos: 61-70.

TONECAS, J. 2012. Cheias nos vales do Cavaco e Catumbela (Angola): constrangimentos geomorfológicos e climáticos. Unpublished MsC Thesis, Universidade de Coimbra. 